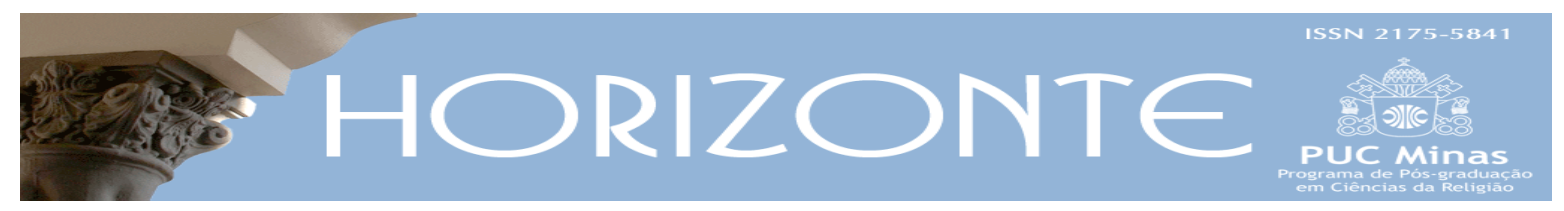

Dossiê: Judaísmo: religião, cultura, nação - Artigo Original ๑응

\title{
A exegese de Fílon de Alexandria e o peculiar caso de Noé como Deucalião
}

\author{
The exegesis of Philo of Alexandria and the peculiar case of Noah as \\ Deucalion
}

Cesar Motta Rios*

\begin{abstract}
Resumo
Fílon de Alexandria (I d.C.) é mencionado frequentemente como exemplo de exegeta que adotava o método da interpretação alegórica. Por vezes, entende-se, de modo pré-concebido, que sua hermenêutica é imaginativa, descuidada e pouco responsável. Neste artigo, a partir de uma pesquisa bibliográfica abrangente e estudo de fontes primárias em suas línguas originais, apresento o alexandrino como um exegeta inserido em seu tempo, dotado de recursos, que observava parâmetros. Além de uma apresentação inicial, abordo detidamente um caso específico: a identificação que Fílon faz entre Noé e Deucalião em Sobre Penas e Recompensas 23. Meu objetivo é compreender como esse procedimento, que é incomum, uma vez que o alexandrino evita recorrer à mitologia comparada, se insere no corpus filoninano. Demonstro que é razoável que não se trate de uma intencional associação entre mitos, mas entre personagens históricos. O trecho não deixa de ser atípico, especialmente quando visto de nossa perspectiva, mas é coerente com a estratégia do exegeta de Alexandria, quando visto a partir da perspectiva dele.
\end{abstract}

Palavras-chave: Fílon de Alexandria; exegese; Noé; Deucalião; mitologia.

\begin{abstract}
Philo of Alexandria (I AD) is frequently named as an example of exegete that adopted the method of allegorical interpretation. Sometimes it is understood in a preconceived way, as if his hermeneutics were imaginative, careless and barely responsible. In this article, through a bibliographical research and the study of primary sources in their original languages, I introduce the Alexandrian as an exegete of his time, resourceful, who took parameters into account. Besides an introductory presentation of the exegete, I approach meticulously a single specific case: the identification that Philo establishes between Noah and Deucalion in On Rewards and Punishments 23. My objective is to understand how this procedure, which is unusual, since the Alexandrian avoided the method of comparative mythology throughout his works, is inserted in Philonic corpus. I demonstrate that it is reasonable that it is not an intentional association between myths, but between historic characters. The passage is still atypical, especially when it is observed from our perspective, but it is coherent with the Alexandrian exegete's strategy when observed from his perspective.
\end{abstract}

Keywords: Philo of Alexandria; exegesis; Noah; Deucalion; mythology.

Artigo submetido em 11 de agosto de 2017 e aprovado em 29 de abril de 2019.

*Doutor em Estudos Literários pela UFMG. País de origem: Brasil. E-mail: cesarmottarios@gmail.com 


\section{Introdução}

Fílon de Alexandria costuma ser descrito como um filósofo judeu que conciliou a Torah com a filosofia platônica. Essa apresentação não é a mais acertada. Sua apropriação da filosofia não se restringe ao platonismo. Além disso, sua lida conjunta com o texto da Torah e a filosofia não deve ser vista como atividade de um conciliador que, previamente integrado em um dos lados, resolve conciliá-lo com o outro (RIOS, 2015). Por fim, é preciso suspeitar que o termo "filósofo" não seja o melhor para descrever o responsável por uma grande série de comentários do Pentateuco. Fílon é melhor apresentado como um exegeta; um exegeta bem inserido em seu tempo e contexto (BORGEN, 2005).

Outra referência a Fílon comumente encontrada, mais especificamente quando se trata de hermenêutica, é aquela que o assinala como exemplo de (mero) alegorista. ${ }^{1} \mathrm{O}$ título de alegorista reflete realmente um método que se realça em boa parte do corpus filoniano. Não obstante, pode levar a simplificações contraproducentes. Dizer que Fílon é alegorista não esgota, ou melhor, não chega a expressar minimamente sequer a riqueza e a dinâmica de sua obra e de seu empreendimento hermenêutico.

Ainda que com alguma limitação, pode-se apresentar Fílon como um exegeta prolixo, culto e atento às questões de seu tempo. $\mathrm{O}$ fato de ser prolixo (aliado à preservação de parte considerável de sua obra por cristãos ${ }^{2}$ ) faz com que ele seja um dos autores antigos que mais textos nos legou sobre a Bíblia, as tradições e o povo judeu. Como era culto, refletia em sua escrita uma ampla gama do conhecimento que circulava em seu contexto, servindo como fonte para pesquisas

\footnotetext{
${ }^{1}$ Inclusive, inicialmente, os escritos de Fílon foram mencionados por escritores cristãos quase exclusivamente por sua interpretação alegórica. O primeiro a considerar a obra do alexandrino de modo mais amplo, incluindo seus tratados históricos e filosóficos, foi Eusébio de Cesareia (NIEHOFF, 2015).

${ }^{2}$ A obra de Fílon foi preservada por cristãos, como aconteceu em geral com escritos judaicos em grego. Atualmente, percebe-se interesse no meio judaico, o que se verifica inclusive no mercado editorial com a publicação em andamento da série Torah from Alexandria: Philo as a Biblical Commentator, escrita pelo rabino Michael L. Samuel e editada pela Kodesh Press. (2014)
} 
não só sobre o próprio pensamento.3 Quanto ao tempo, o fato de ter nascido cerca de uma ou duas décadas antes da virada das eras o faz contemporâneo de Hillel, Jesus e, em idade mais avançada, de Paulo e Sêneca. 4

O presente artigo oferece uma visão atualizada da hermenêutica filoniana. $\mathrm{O}$ esforço se justifica pela importância do autor para a história da interpretação da Escritura. Por outro lado, também, a reflexão sobre o passado, com suas tensões e estratégias, propicia, ainda que indiretamente, oportunidade para reflexões sobre a hermenêutica em si. Assim, abrem-se caminhos ou se fornecem elementos para se pensar também a respeito do presente. No mínimo, evidencia-se a inexistência de neutralidade de contexto e perspectiva em qualquer trabalho interpretativo, com seus pressupostos e suas estratégias.

Primeiramente, em diálogo com outros pesquisadores, a partir de uma pesquisa bibliográfica abrangente, apresento Fílon como exegeta articulado com seu tempo, ciente de suas escolhas e dotado de recursos. Em seguida, exemplifico a complexidade da exegese filoniana pela consideração minuciosa de um passo específico e atípico em sua obra: a identificação de um personagem da Torah (Noé) com um personagem mítico do arquivo grego (Deucalião). Na conclusão, considero o conjunto do que foi desenvolvido, reinserindo o caso estudado no entendimento a respeito de Fílon como exegeta. Ademais, ressalto como o estudo beneficia reflexões que transcendem o âmbito dos estudos filonianos.

\footnotetext{
${ }^{3}$ David Runia (1990, p. 185-186) bem observa que o estudo da obra de Fílon é válido para quem se envolve com pelo menos uma das seguintes áreas do conhecimento: Literatura judaico-helenística, judaísmo do Segundo Templo, Novo Testamento, Patrística e gnosticismo, cultura helenística e filosofia grega. Apesar das possíveis inter-relações viabilizadas por essas áreas tangenciais, Larry Hurtado opina que se deve privilegiar o estudo da obra Fílon por si mesma, evitando sua instrumentalização imediata em compar ações com o Novo Testamento, por exemplo (HURTADO, 2004). É sensato que a obra de Fílon deva ser pesquisada primordialmente por sua própria importância, mas não se deve desmerecer imediatamente qualquer aproximação. Mesmo em um assunto já muito investigado como o uso/conceito de lógos em Fílon e no prólogo joanino, é possível ainda encontrar reflexões comparativas instigantes (BOYARIN, 2001). Mais recentemente, em um estudo criativo e interessante, Peder Borgen demonstrou a utilidade de se considerar dois tratados de Fílon para se pensar a questão do gênero dos Evangelhos (BORGEN, 2014). Esses exemplos bem-sucedidos, contudo, só ressaltam a necessidade de se conhecer bem Fílon por si mesmo antes de qualquer empreendimento comparatista.

${ }^{4}$ A datação se baseia no fato de que, em Embaixada a Calígula, Fílon relata que era o mais velho dentre os enviados em uma comitiva para audiência com Calígula, acontecimento do início da década de 40 D.C.. Sobre essa definição cronológica e sua relevância, (MARTín, 2009, p. 10).
} 


\section{Fílon como exegeta}

Como se disse antes, a obra de Fílon é melhor descrita como trabalho de um exegeta do que de um filósofo. Antes da referida obra de Peder Borgen (2005), a tese doutoral de Valentin Nikiprowetzky (1974) se coloca como um marco decisivo para o estabelecimento dessa perspectiva. O pesquisador demonstra que Fílon não cria um sistema abstrato independente, mas que está constantemente na dependência do texto que comenta, o Pentateuco. Fílon é um comentador das Escrituras. ${ }^{5} \mathrm{E}$ as Escrituras que ele interpreta estão em grego, não em hebraico, embora recorra ao idioma semítico quando se trata de interpretar nomes de pessoas ou lugares ${ }^{6}$ Contra Aslanoff (1998, p. 271), deve-se perceber que Fílon não vê no uso da tradução grega qualquer restrição a seu trabalho exegético. Isso se deve à apreciação positiva e espiritual que tem com relação à LXX (Sobre a vida de Moisés 2.37-40).

Estudos a respeito das origens do método interpretativo mais utilizado por Fílon de Alexandria, a alegorese ${ }^{7}$, foram empreendidos por diversos pesquisadores desde meados do século passado. Émile Bréhier (1950) propõe uma aproximação com a tradição neopitagórica, a partir de uma comparação do método filoniano com o que se encontra na Tábua de Cebes. Outros autores, entre os quais Jean Pépin (1958), consideram pertinente uma aproximação entre a interpretação de Fílon e a dos antigos estoicos. Essa hipótese, contudo, não é livre de controvérsias (LONG, 1997), e deve ser tratada com cautela. Mais recentemente, Ekaterina Motusova (2010) retomou de certa forma a proposta de Bréhier, a respeito de uma relação com os neopitagóricos, apresentando uma argumentação mais pertinente. ${ }^{8}$ Katell Berthelot (2012), por sua vez, defende uma relação mais próxima com o que

\footnotetext{
${ }^{5}$ Essa dependência do texto bíblico, por outro lado, fez com que, anteriormente, Wolfson (1982) apresentasse Fílon como fundador de um novo modo de se fazer filosofia, que seria seguido por judeus, cristãos e muçulmanos ao longo da Idade Média.

${ }^{6}$ A respeito desse recurso à etimologia hebraica, uma obra de grande utilidade é "Etymology in Early Jewish Interpretation: the Hebrew names in Philo"' (GRABBE, 1988).

${ }^{7} \mathrm{O}$ termo alegorese é cunhado nas línguas modernas como modo de expressar a interpretação que considera o texto interpretado como escrito em forma de alegoria.

${ }^{8}$ A fraqueza da proposta de Bréhier está na escolha da Tábua de Cebes como documento a comparar com a obra de Fílon. Trata-se de interpretação de uma imagem, não de texto. A interpretação alegórica de Fílon depende fundamentalmente do texto em si, e não somente das imagens sugeridas por ele. A esse respeito ver: (RIOS, 2009).
} 
se encontra no meio neoplatonista, a partir de uma comparação com De Antro Nympharum de Porfírio. Essa diversidade de posições revela a persistência de uma inquietante indeterminação, mas, ao mesmo tempo, permitem que se entrevejam possibilidades de diálogos enriquecedores. 9

Quanto a aspectos do uso da alegorese por parte de Fílon, também muito se desenvolveu em pesquisas desde a segunda metade do século passado. Jacques Cazeaux procurou em diversas publicações demonstrar algo de vital importância para a correta apreensão da obra filoniana: há um sistema unificador na interpretação e escrita de Fílon. Não se trata, portanto, como se costuma pensar, de uma escrita sem planejamento e desajustada (CAZEAUX, 1998, p. 293). Embora seja possível suspeitar de algum exagero em seu reconhecimento de uma unidade perfeita e estruturação absoluta, Cazeaux faz perceber algo que precisa estar em mente quando se lê Fílon: uma referência rápida e aparentemente despretensiosa a um significado oculto pode esclarecer toda uma unidade argumentativa, por se conectar com uma série bem definida de significados.

David Runia reafirma a existência de uma lógica estruturante no texto de Fílon e reconhece que o texto bíblico é que fornece tal esqueleto ao discurso do intérprete (RUNIA, 1984). Essa consideração da importância do texto bíblico, antes levantada por Nikiprowetzky, como visto, conduzirá Runia à afirmação de que um estudo sobre qualquer tema ou afirmação de Fílon deveria levar em consideração o contexto interpretativo e o problema exegético em questão (RUNIA, 1990).

A partir do que já se vinha desenvolvendo, Peder Borgen (2005) direciona a atenção para o fato de que Fílon desenvolve uma escrita e um empreendimento exegético bem inserido em seu contexto histórico-cultural. David Dawson (1992, p.

\footnotetext{
${ }^{9}$ Percebe-se que os textos trazidos para comparação com vistas à identificação das origens do método de Fílon são sempre do arquivo grego/helenístico. Convém, pois, ressaltar que, ao se dizer que o judeu alexandrino recebe influência helênica em certa faceta de sua obra, não se deve entender que ele esteja fora do helenismo e se aproveite de um dado somente por opção, ou que tome uma noçã o e um método prontos e os mantenha inalterados. Nesse encontro grego-judaico, que já estava em andamento havia séculos, a soma de $A$ e $B$ não gera exatamente um $A B$, mas um $C$, no qual se percebe a emergência de traços ausentes tanto em $A$ quanto em $B$. Fenômeno semelhante, oriundo do encontro entre filosofia grega e texto bíblico na exegese de Fílon, foi nomeado por Nikiprowetzky como "mutação qualitativa" (NIKIPROWETZKY, 1974, p. 326). Esse aspecto deve ser considerado quando se estuda a presença de elementos "gregos" não somente no método exegético, mas também nos temas da exegese filoniana, o que não é também desconhecido. (AMIR, 1984; DILLON, 1981).
} 
74), por sua vez, propunha que era "inequivocamente claro que, para Fílon, a interpretação alegórica é um esforço para tornar judaica a cultura grega, em vez de dissolver a identidade judaica na cultura grega”. A hermenêutica e o tenso contexto intercultural se veem relacionados. ${ }^{10}$

É justamente uma peculiaridade de seu contexto que fará com que, nas últimas décadas, fosse levantada a seguinte questão: Se Fílon vivia no contexto alexandrino, por que usava um método interpretativo tão diferente do que se desenvolvia no famoso Museu? Por que o alexandrino enfatiza o método alegórico, que acabará por ser característica marcante da escola alexandrina dos teólogos cristãos em períodos subsequentes?

Parece óbvio que Cyril Aslanoff (1998, p. 283) erra ao afirmar que, por causa do contexto helenístico em que vivia, era inevitável que Fílon utilizasse o método alegórico. Havia uma alternativa muito convidativa justo em sua cidade. ${ }^{11}$ Também equivocado parece estar Folker Siegert (2011), que acusa Fílon de negligenciar os métodos do Museu, o que teria tido influência negativa também sobre os teólogos cristãos subsequentes. Siegert sugere que se veja Fílon como um tanto ignorante a respeito dos métodos peripatéticos de Alexandria. Desconsidera que, anos antes, Adam Kamesar (1997) percebia, a partir de uma questão bem pontual, que o alexandrino estava atento, e apresentava elos entre sua abordagem da Bíblia e os métodos do Museu.

Mais recentemente, Maren Niehoff desenvolveu uma pesquisa que aprofunda e corrobora a percepção que Kamesar tivera. Através de uma incursão por diferentes textos atribuídos ao judaísmo alexandrino, a pesquisadora demonstra que vários autores judeus estavam muito cientes dos métodos praticados na cidade. O caso de Fílon não seria diferente. Ele teria amplo domínio

\footnotetext{
${ }^{10}$ Curiosamente, por vezes, há alguma tensão e sensibilidade também no contexto do estudo da hermenêutica de Fílon, sobretudo quando algo vislumbrado em seu método é comparável com elementos do texto do Novo Testamento. Um exemplo está na discussão sobre a não aplicação do termo "tipologia" a certa espécie de interpretação alegórica de Fílon (NAJMAN, 2003).

${ }^{11}$ Refiro-me ao Museu e seus estudos, mas também convém lembrar que a existência de judeus literalistas no contexto de Fílon, referidos em sua obra inclusive, é fato bem conhecido. Na primeira metade do século passado, Shroyer já havia dedicado um considerável esforço para refletir a respeito (SHROYER, 1936).
} 
da abordagem peripatética, aplicava alguma de suas técnicas, mas evitava outros procedimentos, que julgava inadequados para o estudo da Escritura: especialmente, a busca por trechos espúrios e a mitologia comparada. O recurso à alegorese não seria, portanto, algo inevitável ou fruto de negligência, mas uma opção consciente com vistas a afirmar que certas dificuldades do texto bíblico seriam somente aparentes, resolvendo-se pela aplicação da leitura apropriada, em busca do sentido mais profundo, e não pela mutilação da narrativa ou por sua consideração como mero mito (NIEHOFF, 2011, p. 133-151).

E mesmo essa opção pela alegoria não representaria uma definição apaziguadora simplesmente. Fílon ainda se movimenta estrategicamente no âmbito da alegorese, não concordando imediatamente com todos os que a praticam. Alegoristas que desconsideravam absolutamente o sentido literal da Lei receberam crítica incisiva e irônica: desconhecem todo tipo de organização social humana,

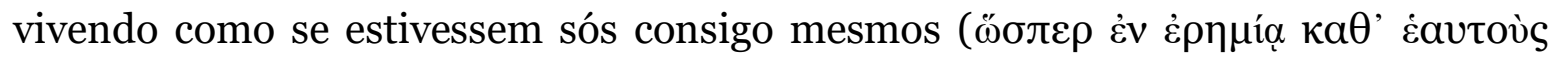

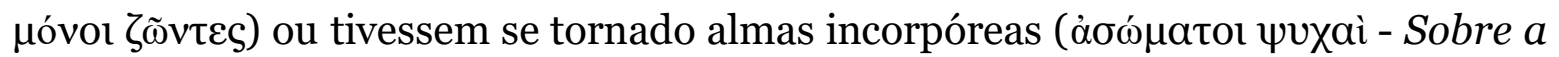
Migração de Abraão 90). (HAY, 1997). Fílon está disposto a desprezar alguns resultados de outros alegoristas judeus, propondo seu modo próprio de se valer do método (GOULET, 2005).

Faz-se necessário considerar com cuidado os métodos usados por Fílon, atentando para as possíveis relações de suas estratégias interpretativas e textuais com seu contexto e as tensões que estavam diante de si. Não basta aplicar a ele o rótulo de alegorista, como se, com essa simples afirmação, tudo se compreendesse a seu respeito. No sentido de enfrentar essa complexidade inevitável, passo a avaliar uma exceção significativa no discurso exegético filoniano, em que o alexandrino parece ter acolhido o método da mitologia comparada em seu trabalho. ${ }^{12}$

\footnotetext{
${ }^{12} \mathrm{O}$ trecho em análise no presente artigo (Sobre Penas e Recompensas 23) não aparece mencionado na referida pesquisa de Maren Niehoff (2011).
} 


\section{Noé e Deucalião em Fílon}

Noé é personagem razoavelmente importante na escrita exegética de Fílon. Junto com Enoque e Enos, constitui uma tríade ( $\tau \rho$ iòs), o que lhe confere algum destaque, ainda que não tão grande quanto aquele que recebem os integrantes de

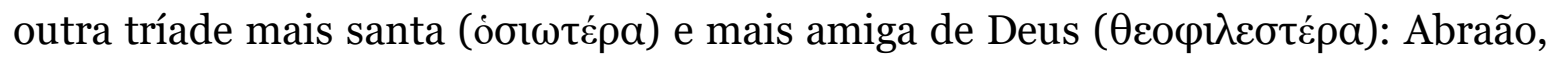
Isaque e Jacó (Sobre Penas e Recompensas 24).

Em Sobre Abraão, Fílon apresenta Noé da seguinte maneira:

Por conseguinte, adequadamente, depois do que se converteu, colocou na

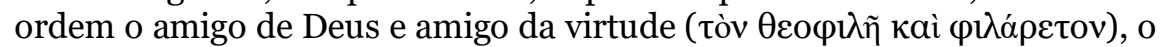

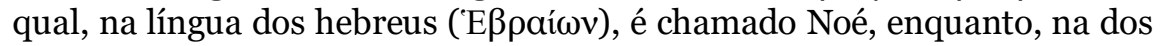

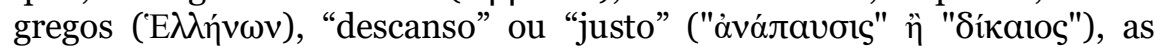
mais pertinentes designações para um sábio. (Sobre Abraão 27).

O recurso à tradução do nome do hebraico para o grego é procedimento exegético comum na obra filoniana. Ele o faz seguidamente quando o significado do nome é oportuno para a exposição de certo sentido que ele entende ter a narrativa. No presente caso, o nome Noé, נִ exegeta relaciona esse descanso com a ausência de páthos, alinhando-se com o pensamento estoico. ${ }^{14}$ Já a associação com "justo” extrapola a simples tradução, e recorre a um dado da narrativa. Em Gn 6,9, versículo citado por Fílon no parágrafo seguinte, lê-se: "Noé era um ser humano justo, perfeito na sua geração" 15. Convém observar que, no prosseguimento do texto, o exegeta se propõe a explicar por que Noé era "justo na sua geração" e não simplesmente "justo". Para tanto, descreve a situação degradada do povo e reconta a sua destruição pelo dilúvio, como bem observa John Collins, atendo-se ao sentido histórico do texto bíblico (COLLINS, 2012, p. 410). Com esse fato, enfatizo que o tratamento alegórico não exclui a possibilidade de uma paralela consideração do sentido literal. Interpretar o nome de Noé alegoricamente não implica em negar que ele tenha sido um homem de carne e osso.

\footnotetext{
${ }^{13}$ O Texto Massorético simplesmente diferencia o nome próprio do uso do substantivo comum pela colocação de holem (@ַ) no nome e holem-vaw (1 - Ester 9,16, 2Cr 6,41) no uso como substantivo comum.

${ }^{14}$ Nota na edição espanhola das obras de Fílon de Alejandría (2009-2016, p. 143, v. IV ).

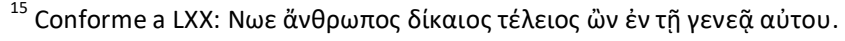


Adiante, no encerramento do relato sobre Noé em Sobre Abraão, Fílon observa: "Com efeito, Deus considerou digno que ele fosse o fim e o princípio da nossa raça. Por um lado, fim daqueles anteriores ao dilúvio. Por outro lado, princípio dos posteriores ao dilúvio" (Sobre Abraão 46).

Em Sobre Penas e Recompensas, Fílon reproduz essa mesma consideração, mas apresenta o nome de Noé de modo completamente diverso:

Pois o Criador considerou digno que a mesma pessoa fosse tanto o fim da geração condenada quanto o início da geração livre de culpa, ensinando com obras, não palavras, aqueles que dizem que o mundo é desprovido de providência, que, conforme a lei que ele introduziu na natureza do universo, as miríades todas dentre os seres humanos que viveram com a

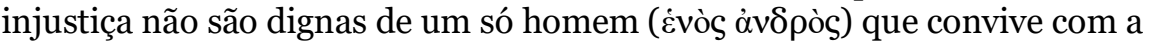
justiça. Este, os gregos o nomeiam "Deucalião", mas os caldeus, "Noé”, em cujo tempo, aconteceu de sobrevir o grande dilúvio. (Sobre penas e recompensas 23 ).

Percebe-se que, aqui, há uma especificidade na forma de se “traduzir” Noé do hebraico para o grego. O que, em Sobre Abraão, era uma tradução simples (“descanso”) acrescida de um traço característico do personagem em sua narrativa (“justo”), agora se realiza por meio de uma associação entre personagens que seriam, em princípio, distintos. Em vez de procurar o sentido profundo do nome de Noé e acessar sua narrativa já a partir dessa incursão no plano alegórico, Fílon identifica duas narrativas de arquivos distintos, o hebraico/judaico e o grego, como sendo uma só. Nada semelhante ocorre nas outras menções de Noé, nem tampouco na apresentação de Enos e Enoque que aparecem imediatamente antes em Sobre Penas e Recompensas. Aquele que os Caldeus chamam de Enós, o qual representa aquele que recebe o prêmio pela esperança, "traduzido para a língua grega, é

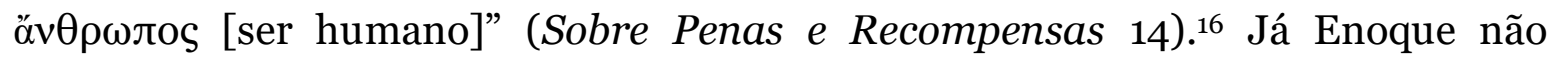
aparece explicitamente nomeado, sendo referido pela citação de $\mathrm{Gn}$ 5,24, não havendo tratamento do nome em si no trecho.

Como visto no tópico anterior, Maren Niehoff demonstrou que Fílon evita deliberadamente a prática de uma mitologia comparada. De fato, a apreciação do

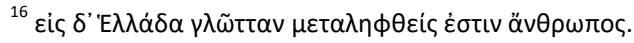


alexandrino dos mitos é negativa, e ele nega que a Torah tenha um caráter mítico. Inclusive os episódios mais incompatíveis com a realidade ordinária, não deveriam ser vistos como mitos. Em Sobre os Gigantes, Fílon nega que a referência a gigantes no capítulo 6 do Gênesis seja relacionada um caráter mítico da narrativa. De fato, ele não afirma claramente a historicidade do episódio, mas sugere que se trate de um ensino comunicado alegoricamente:

"E havia gigantes sobre a terra naqueles dias" (Gn 6,4). Talvez alguém suponha que o legislador está se referindo a coisas contadas por parte dos poetas sobre os gigantes. Mas são coisas que estão tão distantes quanto possível do moldar mitos e que são dignas de andar pelas trilhas da verdade, só desta. [...] Então, ele não põe em discussão absolutamente nenhum mito sobre gigantes, mas aquilo quer te mostrar: que alguns homens são nascidos da terra, outros do céu e outros de Deus. (Sobre os Gigantes 58 e 60) ${ }^{17}$.

É significativo, ainda, que, na parte inicial do próprio tratado Sobre Penas e Recompensas, o exegeta constrói um paralelo entre algo comunicado por um mito grego e algo comunicado pela Torah:

Os gregos dizem que aquele antigo Triptólemo, elevando-se às alturas sobre dragões alados, semeou o fruto do trigo por toda a terra, para que, em vez da alimentação baseada em bolotas, a raça dos seres humanos tivesse um alimento cultivado, útil e saboroso. Isso, então, que é uma invenção de mito, que procura a sofística em vez da sabedoria e a mágica em vez da verdade, do mesmo modo que muitas outras coisas, seja deixado para os que têm por hábito ocuparem-se com coisas maravilhosas. Pois, desde o princípio, de uma só vez no começo da criação do universo, Deus preparou antecipadamente as coisas necessárias, fazendo com que saíssem da terra, e, sobretudo, para a raça dos seres humanos, à qual concedeu graciosamente a liderança sobre todos os seres nascidos da terra. (Sobre Penas e Recompensas 8-9).

Como se vê, o mito é absolutamente negado, enquanto é afirmada a veracidade da lição da Torah. Há uma hierarquia discursiva sendo afirmada.

Deucalião e Noé, em Sobre Penas e Recompensas 23, formam, pois, uma exceção notável, visto que o paralelo é acolhido no texto, como observa Bloch, sem que haja uma disposição apologética (BLOCH, 2011, p. 199). Essa associação, decerto, não seria destacada por si mesma. É somente sua existência isolada que

\footnotetext{
${ }^{17}$ Ao silenciar sobre a historicidade e recorrer somente ao sentido alegórico, Fílon parece admitir haver uma formulação mítica no texto que interpreta (MARTín, 2002; KAMESAR, 1998). Não obstante, é preciso reconhecer que a forma como Fílon evita a associação en tre o texto bíblico e o termo $\mu \tilde{\theta}$ os é importante e não deve ser desconsiderada.
} 
lhe concede destaque. De fato, nada há de inusitado ou engenhoso na aproximação em si, porque a narrativa de Noé na Torah e a de Deucalião na tradição grega (ou greco-romana) têm parecenças por demais óbvias.

Referências a Deucalião como sobrevivente de grande dilúvio aparecem em obras notáveis dos gregos, como o Timeu (22 a-d) de Platão. Certamente, o relato era bem conhecido, e não preservado em uma única forma. Por vezes, há dados completamente estranhos ao que se narra na Torah a respeito de Noé. Píndaro, por exemplo, afirma que Deucalião e sua esposa deram origem a uma descendência de pedra ( $\lambda$ îuvov yóvov - Olímpicas IX, 43-45).

Versões cronologicamente mais aproximadas de Fílon apresentam semelhanças mais ressaltadas com o Gênesis, contendo dados não presentes nas obras gregas anteriores (dentre as preservadas até nosso tempo). Plutarco afirma que os contadores de mitos ( $\mu v \theta 0 \lambda$ ójoı) dizem que Deucalião enviou uma pomba

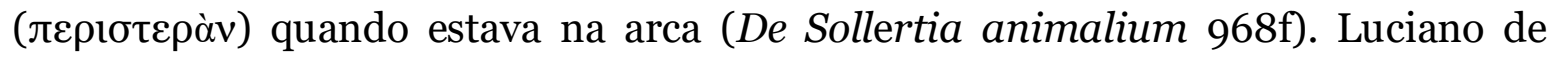
Samósata apresenta o mito ( $\mu$ ṽos) a respeito de Deucalião, que seria contado entre os gregos ( $\dot{\varepsilon} v$ "E $\mathrm{k} \lambda \eta \eta \sigma v)$. O personagem aparece entrando na arca com seus filhos e mulheres, acompanhado também por animais domésticos e selvagens, que

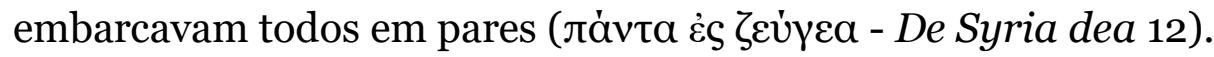

Hilhorst chegará a afirmar que, no caso desses dois autores, há indícios de influência oriunda do relato da Torah. Diferenças pontuais sugeririam tratar-se de influência indireta, quiçá por uma transmissão oral do relato encontrado na LXX (HILHORST, 1998, p. 61-62). ${ }^{18}$ Ainda que esse entendimento seja questionável, o fato de ser construído a partir das semelhanças verificadas no cotejo das fontes evidencia a notoriedade dessas semelhanças, que seriam contempladas pelo exegeta alexandrino.

\footnotetext{
${ }^{18}$ Obviamente, pode-se pensar em influência mais antiga, mesopotâmica, em princípio. 0 autor se mostra ciente dessa possibilidade. Ainda assim, possivelmente concentrando-se em Noé e não atentando suficientemente para Atra-hasīs, sua análise o encaminha à afirmação da influência indireta com relação ao texto da LXX. Como procuro explicitar no texto, o fato de haver ou não especificamente essa influência não é diretamente importante para a presente reflexão. $O$ que ressalto é a semelhança, que é suficiente para levar o pesquisador a afirmar a influência. Ainda que a análise e a conclusão não estejam acertadas, o dado levantado, que é real, fica ressaltado.
} 
Plutarco e Luciano são autores posteriores a Fílon, mas podem revelar versões que já circulavam na primeira metade do século I d.C.. A forma como introduzem suas palavras, com a referência aos "contadores de mitos" ou mito contado "entre os gregos", indica de modo razoavelmente confiável que não inventam simplesmente os dados que apresentam, mas que, em alguma medida, referem-se a relatos em circulação em seu tempo. Além desses dois autores, convém considerar Ovídio, que, apesar da diferença linguística, já que não escreve em grego, é importante por escrever poucas décadas antes de Fílon. Encontra-se algo considerável em seu relato. Nas Metamorfoses, está registrada uma versão do mito de Deucalião que, por um lado, contém elementos muito diferentes daqueles lidos no relato de Noé. Não há família e animais, mas Deucalião e sua esposa somente. E não navegam em uma arca gigantesca, mas num pequeno barco (parva rate - Metamorfoses I 319). Por outro lado, o rei dos deuses decide eliminar a raça humana por sua degradação (I 188) e sobre o homem a se salvar, Deucalião, o poeta afirma: "Não havia nenhum homem melhor (melior) que ele, ou mais amante do direito (amantior aequi)" (I 322-323). Considerando que ser justo em comparação com os seus contemporâneos é algo destacado por Fílon em sua apreciação de Noé, é significativo que uma caracterização bem semelhante de Deucalião circulasse próximo de seu tempo.

A semelhança muito nítida, especialmente se considerarmos que Fílon teria conhecido as versões que circulavam mais perto de seu tempo, seria um motivo para a exceção sobre a qual estou refletindo? Em princípio, pode-se suspeitar que sim. ${ }^{19}$ Mas o motivo, suficiente para viabilizar a identificação, não é suficiente para impedir que o procedimento tivesse consequência indesejada. Colocar o relato sobre Noé como identificado com o de Deucalião nos parece implicar em uma admissão de que o caráter mítico de Deucalião também se encontra no âmbito da Torah. ${ }^{20}$ Mas é preciso considerar a possibilidade do inverso, isto é, que Fílon

\footnotetext{
${ }^{19}$ A presença considerável da identificação de Noé como Deucalião em autores cristãos antigos como Justino Mártir, Teófilo de Antioquia e outros (COLLINS, 2012, p. 416-419) ressalta o fato de que a semelhança marcante favorecia o procedimento.

${ }^{20}$ Como exemplo dessa possibilidade implicada na aproximação, convém lembrar de uma acusação registrada no Contra Celso (IV, 41) de Orígenes. Ao contarem o relato de Noé, os cristãos estariam rebaixando e tecendo uma versão fraudulenta de Deucalião

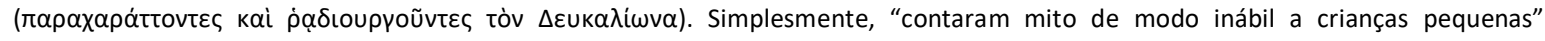

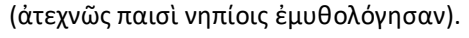


entenda que a realidade não-mítica que ele entende ter Noé seja também a de Deucalião. Tratar-se-ia, nesse caso, de comparação não de mitos, mas de figuras históricas. A forma como aparece a referência ao dilúvio, como evento ocorrido em dado tempo, pode favorecer esse entendimento. Portanto, torno a citar o fechamento da passagem; agora, com grifo próprio: “em cujo tempo, aconteceu de sobrevir o grande dilúvio”. ${ }^{21}$

Decerto, resta ainda outra possibilidade, se atentamos para o que Fílon resolve a respeito do relato de Gênesis 6, no trecho antes citado de Sobre os Gigantes. Um texto pode ter o caráter mítico negado por comunicar alegoricamente um ensino verdadeiro. Se, hoje, entendemos que o que os antigos fizeram foi interpretar mitos alegoricamente, de modo a inserir neles ensinos pretendidos, parece que o alexandrino podia entender diferente. A narrativa didática poderia não ser histórica e, ainda assim, não ser mito? O contrário de mítico não é histórico, mas verdadeiro? A resposta a essa pergunta não é simples, uma vez que não há uma negação explícita da historicidade da narrativa bíblica. ${ }^{22}$

A propósito da semelhança entre o relato da Torre de Babel e mitos conhecidos entre os gregos, Fílon afirma que alguns detratores diziam que os judeus riam de mitos semelhantes aos encontrados em seu livro sagrado quando os viam em outras fontes (Sobre a confusão das línguas 2). ${ }^{23} \mathrm{Em}$ seguida, o alexandrino exemplifica as comparações que eram feitas com mitos de outras tradições, para, por fim, encaminhando-se ao estudo alegórico do episódio, afirmar que deixaria a refutação dessas comparações a cargo de intérpretes do Pentateuco que se dedicavam ao estudo do sentido literal (Sobre a confusão das línguas 14). Ou seja, embora ele não se dedique à tarefa, não nega que, mesmo no sentido da

\footnotetext{
${ }^{21}$ Ainda que sem discutir a fundo as implicações, Louis Feldman entende nesse sentido o trecho. Considera que o tratado Sobre penas $e$ recompensas foi direcionado a judeus desviantes, e que a associação entre Noé e Deucalião por parte de Fílon, que não duvidava da historicidade dos eventos narrados na Torah, teria o propósito de atestar o caráter acurado da cronologia bíblica (FELDMAN, 2003, p. 402-404).

${ }^{22}$ A afirmação de um sentido alegórico não implica necessariamente na negação do sentido literal. É verdade, contudo, que o acesso ao sentido alegórico pode ser justificado por uma desconstrução tão vigorosa da pertinência do sentido literal que a consideração deste parece impraticável (Sobre os Sonhos 1.92-100).

${ }^{23}$ É possível especular, mas sem indício algum, que esses detratores referidos por Fílon fizessem acusação semelhante àquela atribuída a Celso por Orígenes a respeito do paralelo entre Noé e Deucalião. Ver nota 21.
} 
superfície, haja uma explicação que seja suficiente para desfazer a confusão entre o relato bíblico e os mitos.

O caso de Sobre a confusão das línguas faz lembrar que restrição de Fílon à mitologia comparada não deve nos fazer pensar que ignorava os mitos gregos. Pelo contrário, tinha um conhecimento bastante suficiente, claramente percebido na refutação que tece a partir do arquivo mítico grego contra Calígula, que queria fazer-se Deus (Embaixada a Calígula 78-113). ${ }^{24}$ Ademais, não se deve pensar que toda e qualquer aproximação entre elementos da Torah e da tradição grega fosse repudiada. O próprio costume de traduzir os nomes do hebraico ao grego indica outra postura. Além disso, comparações pontuais são utilizadas quando a argumentação o requer ou delas se beneficia. Em Sobre os Gigantes, a interdição das imagens na legislação mosaica é referida de forma a fazer o leitor lembrar da restrição dos poetas na República de Platão (1929):

Por essa razão, [Moisés] expulsou de sua república artes bem consideradas e escrupulosas, a pintura e a escultura, porque, falsificando a natureza da verdade, manufaturam enganos e sofismas através dos olhos para almas fáceis de se desviar. (Sobre os Gigantes 59, grifo nosso).

Quanto à comparação entre pessoas, há outro caso relevante na obra filoniana. Em Sobre os Sonhos, o exegeta tece uma aproximação entre Sócrates e Taré, o pai de Abraão. No trecho, interpreta a migração de Taré com sua família para Harã como um ensino a respeito do conhecer-se a si mesmo (não como mera narrativa histórica!), deixando de procurar as coisas longínquas (da astronomia) antes de uma investigação do que está mais próximo (Sobre os Sonhos 52). Após explicitar esse ensino por meio de um discurso direto atribuído ao próprio o lógos

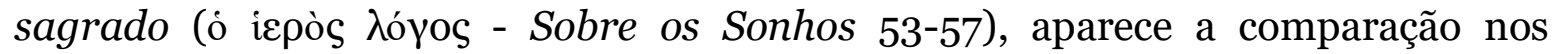
seguintes termos:

Esta figura, os hebreus nomeiam Taré, e os gregos, por sua vez, Sócrates. Pois, verdadeiramente, dizem que este envelheceu na mais rigorosa observação referente ao "conhece-te a ti mesmo", nada filosofando fora das coisas relacionadas a si mesmo. Entretanto, ele era um ser humano, enquanto Taré é o próprio arrazoado a respeito de alguém conhecer a si

\footnotetext{
${ }^{24}$ (RIOS, 2013, p. 313-320).
} 
mesmo, proposto como uma árvore muito bem brotada, para que os amantes da virtude tenham como saciar-se facilmente com um alimento salvador e agradabilíssimo, colhendo para si o fruto da formação de caráter. (Sobre os Sonhos 58) 25.

Há uma dificuldade de entendimento sobre a natureza da identificação proposta. Não parece plausível que Fílon se confunda cronologicamente ao ponto de afirmar que o filósofo ateniense do século V a.C. fosse um contemporâneo de Moisés, no período anterior ao Êxodo. Em uma breve nota, Feldman afirma que, no trecho, Fílon apenas parece equacionar Taré e Sócrates, quando, na verdade, equacionaria "a característica de se ocupar com o si mesmo" (FELDMAN, 2003, p. 402). De fato, o alexandrino parece usar os personagens históricos, colocando-os em paralelo, para demonstrar que a mesma disposição é representada no arquivo grego e no arquivo judaico. Ainda assim, insisto que a formulação da passagem, bem semelhante à de Sobre Penas e Recompensas 23, deve ser valorizada. Ela revela uma abertura para paralelo com personagens históricos, se não por uma identidade absoluta entre os dois, no mínimo, por uma identidade relativa a um ou outro dado específico.

Convém lembrar que o "histórico" não é, em todos os contextos, necessariamente purificado de qualquer episódio minimamente maravilhoso como na concepção moderna, pós-iluminista. Um dilúvio de proporções assustadoras não seria impeditivo infalível para a "historicidade" de um relato. Ademais, se o sentido literal for dificultoso, Fílon pode deixá-lo sem tratamento e passar ao sentido alegórico. A narrativa, assim, não é considerada mítica, ainda que de difícil entendimento literal. Ou seja, ele poderia identificar Noé e Deucalião, mesmo entendendo que os dois são um mesmo personagem de uma narrativa que seria melhor considerada em seu sentido mais profundo.

Em vista de outros movimentos realizados por Fílon em sua obra, a muita semelhança entre Noé e Deucalião e a possibilidade de não se considerar Deucalião

\footnotetext{
${ }^{25}$ Situação parcialmente semelhante acontece em Sobre Abraão 54, em que os três homens que comem com Abraão (Gn 18,2) são associados às três Graças (Xápıtac) da tradição helênica. Obviamente, não aproveita o mito diretamente, mas com a mediação da interpretação estoica. Não há, contudo, no trecho bíblico, personagens nomeados. Fílon pode, então, até mesmo afirmar que, enquanto no discurso ( $\lambda$ ó $\omega$ ) eles são três homens, na obra, isto é, na realidade da ação ( $\varepsilon$ $\rho ү \omega$ ), são três virtudes.
} 
como figura mítica constituem, ao que parece, um fundamento razoável para a exceção de Sobre Prêmios e Recompensas 23.

\section{Conclusão}

A pesquisa a respeito da interpretação bíblica desenvolvida por Fílon de Alexandria, como visto, tem sido desenvolvida consistentemente nas últimas décadas. Estudos recentes têm sugerido que o exegeta alexandrino prioriza o método alegórico não por desconhecer outras possibilidades hermenêuticas ou carecer de sofisticação. O presente artigo retomou essa linha de pensamento a partir da análise de uma exceção: a identificação de Noé com Deucalião, que destoa da prática filoniana de evitar recorrer à mitologia comparada em seus escritos. A reflexão demonstrou que a exceção parece explicável a partir da semelhança destacada entre os relatos de Noé e de Deucalião e da possibilidade de que Deucalião fosse entendido como figura histórica.

A passagem de Sobre Penas e Recompensas 23 não deixa de figurar como excepcional. Contudo, o estudo do que ali se encontra não revela um exegeta descuidado, negligente ou incoerente. Ao contrário, a presente reflexão corrobora a percepção de que Fílon é um exegeta inserido em seu tempo, dotado de recursos variados e dinâmico em sua lida com o texto bíblico. Ele evita certas comparações, mas opta por realizar outras de modo refletido, propositado.

Decerto, seus pressupostos (religiosos, inclusive) o levam a uma ou outra ênfase. O alexandrino lança mão das narrativas gregas, dos mitos, de interpretações desses mitos, mas afirma e exercita uma apreensão do texto bíblico como isento do mítico, do incerto ou duvidoso. Não há descentralização possível no horizonte de Fílon, o judeu. Há, apesar de seu método aparentemente fluido, um esforço pela preservação da Torah como dotada de autoridade e merecedora de reverente observação ${ }^{26}$.

\footnotetext{
${ }^{26} \mathrm{O}$ mesmo intento parece ser um dos fatores que motivaram à agenda anti-hedonista de Fílon (RIOS, 2015b).
} 
Requerer dele uma suspeita com relação a esses pressupostos ou mesmo uma suspensão de todos eles no ato de leitura seria incorrer em anacronismo. Nesse caso, é possível que, ironicamente, uma ou outra acusação contra a qualidade de Fílon como leitor pode ser construída a partir de um problema na qualidade da leitura daquele que o acusa.

Avaliar o trabalho de um exegeta antigo com parâmetros de nossas hermenêuticas desenvolvidas ou adaptadas no pós-iluminismo, sejam aquelas do método histórico-crítico ou reações mais fundamentalistas, promoveria mero julgamento, mas não exatamente compreensão. E, não se promovendo uma melhor compreensão do antigo, não se oportuniza que esse estudo do antigo lance luz sobre aspectos do presente. Por outro lado, a observação detida da complexidade do empreendimento interpretativo de Fílon em seu contexto, com consideração de seus desafios e sua agenda, pode beneficiar o reconhecimento, sempre necessário, de que também as leituras atuais da Bíblia se veem perpassadas por dados de seu contexto religioso ou acadêmico, do pensamento circundante, de expectativas e desafios que requerem a mobilização de diferentes estratégias interpretativas e argumentativas. Decerto, aquilo que fazemos, enquanto o fazemos, costuma parecer aquilo que simples e naturalmente deveria ser feito em circunstâncias neutras. Também essa impressão não nos é exclusiva.

\section{REFERÊNCIAS}

AMIR, Y. The transference of Greek allegories to biblical motifs in Philo. In: GREENSPAHN, F. E.; HILGERT, E.; MACK, B. L. (Ed.). Nourished with peace: studies in Hellenistic Judaism in memory of Samuel Sandmel. Atlanta: Scholars Press, 1984. p. 15-25.

ASLANOFF, Cyril. Exégèse philonienne et herméneutique midrashique: esquisse de confrontation dans une perspective linguistique. In: LÉVY, Carlos (Ed.) Philon

d'Alexandrie et le langage de la philosophie. Paris: Brepols, 1998. p. 266-286.

BERTHELOT, Katell. Philo and the allegorical interpretation of homer in the platonic tradition (with an emphasis on Porphyry's de antro nympharum). In: NIEHOF, Maren.

Homer and the bible in the eyes of ancient interpreters. Leiden: Brill, 2012. p. 155-174. 
BLOCH, René. Moses und der mythos: die auseinandersetzung mit der griechischen mythologie bei jüdisch-hellenistischen autoren. Leiden: Brill, 2011.

BORGEN, Peder. Can Philo's in flaccum and legatio ad gaium be of help? In: BORGEN, Peder. The gospel of john: more light from Philo, Paul and archaeology - the scriptures, tradition, exposition, settings, meaning. Leiden: Brill, 2014. p. 241-260.

BORGEN, Peder. Philo of Alexandria: an exegete for his time. Atlanta: SBL, 2005.

BOYARIN, Daniel. The gospel of the Memra: Jewish binitarianism and the prologue to John. The Harvard Theological Review, Cambridge, v. 94, n. 3, p. 243-284, 2001.

BRÉHIER, Émile. Les idées philosophiques et religieuses de Philon

d'Alexandrie. Paris: Librairie Philosophique J. Vrin, 1950.

CAZEAUX, Jacques. Philon ou la tapisserie de Pénélope. In: LÉVY, Carlos (Ed.). Philon d'Alexandrie et le langage de la philosophie. Paris: Brepols, 1998. p. 287-312.

COLLINS, John. Noah, Deucalion, and the New Testament. Biblica, v. 93, n. 3, p. 403426, 2012.

DAWSON, David. Allegorical readers and cultural revision in ancient Alexandria. Los Angeles: University of California Press, 1992.

DILLON, John. Ganymede as the logos: Traces of a forgotten allegorization in Philo. Classical Quarterly, Cambridge, v. 31, n. 1, p. 183-185, may, 1981.

EDIDERUNT, Karl Elliger; RUDOLPH, Wilhelm. Biblia hebraica stuttgartensia. Editio quinta emendate opera Adrian Schenker. Stuttgart: Deutsche Bibelgesellschaft, 1997.

FELDMAN, L. Questions about the great flood, as viewed by Philo, pseudo-Philo, Josephus, and the Rabbis. Zeitschrift für die Alttestamentliche Wissenschaft, v. 115, p. 401-422, 2003.

FÍLON DE ALEXANDRIA. Filón de Alejandría - Obras completas. Madrid: Trotta, 2009-2016. v. 5 .

FÍLON DE ALEXANDRIA. Philo in ten volumes (and two supplementary volumes). Translated by Francis Henry Colson and G.H. Whitaker. London: Heinemann; Cambridge: Harvard University Press, 1929-1962.

GOULET, R. Allégorisme et anti-allégorisme chez Philon d'Alexandrie. In: DAHAN, G. et GOULET, R. Allégorie des poètes, allégorie des philosophes. Paris: Vrin, 2005. p. 59-87.

GRABBE, Lester L. Etymology in early Jewish interpretation: the Hebrew names in Philo. Atlanta: Scholars Press, 1988. 
HAY, David M. Putting extremism in context: the case of Philo, De Migratione 89-93. The Studia Philonica Annual, Atlanta, v. 9, p. 126-142, 1997.

HILHORST, A. The Noah story: was it known to the greeks? In: MARTÍNEZ, Florentino G.; LUTTIKHUIZEN, Gerard P. Interpretations of the flood. Leiden: Brill, 1998. p. 5665 .

HURTADO, Larry W. Does Philo help explain early Christianity? In: DEINES, R.; NIEBUHR, Karl-Wilhelm (Ed.). Philo and the New Testament-the New Testament and Philo. Tübingen: Mohr Siebeck, 2004. p. 73-92.

KAMESAR, Adam. Philo, the presence of 'Paideutic' myth in the Pentateuch, and the 'principles' or Kephalaia of mosaic discourse. The Studia Philonica Annual, v. 10, p. 34-65, 1998.

KAMESAR, Adam. The literary genres of the Pentateuch as seen from the greek perspective: the testimony of Philo of Alexandria. The Studia Philonica Annual, Atlanta, v. 9, p. 143-189, 1997.

LONG, A. A. Allegory in Philo and etymology in stoicism: A plea for drawing distinctions. The Studia Philonica Annual, Atlanta, v. 9, p. 198-210, 1997.

LUCIANO DE SAMÓSATA. De Syria dea. In: LUCIAN. Anacharsis or athletics. Menippus or the descent into Hades [...]. Translated by A. M. Harmon. Loeb classical library 162. Cambridge: Harvard University Press, 1925.

MARTÍN, José Pablo. Alegoría de Filón sobre los ángeles que miraron con deseo a las hijas de los hombres. Circe de clásicos y modernos, v. 7, p. 261-282, 2002.

MARTÍN, José Pablo. Introducción general. In: ALEXANDRIA, Fílon De. Filón de Alejandría - Obras completas vol. 1. Madrid: Trotta, 2009.

MOTUSOVA, Ekaterina. Allegorical interpretation of the Pentateuch in Alexandria: inscribing Aristobulus and Philo in a wider literary context. The Studia Philonica Annual, Atlanta, v. 22, p. 1-52, 2010.

NAJMAN, Indy. Cain and Abel as character traits: A study in the allegorical typology of Philo of Alexandria. In: LUTTIKHUIZEN, Gerard. Themes in biblical narrative: Jewish and Christian traditions. Leiden: Brill, 2003. p. 107-118.

NIEHOFF, Maren. Eusebius as a reader of Philo. Adamantius, Bologna, v. 21, p. 185-194, 2015 .

NIEHOFF, Maren. Jewish exegesis and Homeric scholarship in Alexandria. Cambridge: Cambridge University Press, 2011.

NIKIPROWETZKY, Valentin. Le commentaire de l'ecriture chez philon d'Alexandrie. Paris: Université de Lille III, 1974. 
ORÍGENES DE ALEXANDRIA. Contra celsum. In: MIGNE, J.-P. (Ed.). Origenis opera omnia, ex variis editionibus et codicibus manu exaratis, gallicanis, italicis [...]. Tomus Primus. Paris: Migne, 1857. (Patrologia Graeca, 11).

OVÍDIO. Metamorphoses 1-8. Translated by Frank Justus Miller. Loeb classical library 42. Cambridge: Harvard University Press, 1916.

PÉPIN, Jean. Mythe et allégorie: Les origines grecques et les contestations judéochrétiennes. Paris: Éditions Montaigne, 1958.

PÍNDARO. Olympian odes. Pythian odes. Edited and translated by William H. Race (Ed.). Loeb classical library 56. Cambridge: Harvard University Press, 1997.

Platẽo. Timaeus. In: PlatẽO. Timaeus. Critias. Cleitophon. Menexenus. Epistles. Translated by R. G. Bury. Loeb classical library 234. Cambridge: Harvard University Press, 1929.

PLUTARCO. De sollertia animalium. In: PLUTARCO. Moralia vol. XII. Loeb classical library 406. Cambridge: Harvard University Press, 1957.

RIOS, C. M. O próprio e o comum: rastros da interculturalidade na escrita de Fílon de Alexandria. Belo Horizonte, 2013 . 403f. Tese (Doutorado). Programa de Pós-Graduação em Estudos Literários - Faculdade de Letras, Universidade Federal de Minas Gerais.

RIOS, C. M. O que vês? / O que lês?: imagináveis aproximações entre Fílon e Zacarias. Nuntius Antiquus, Belo Horizonte, v. 3, p. 85-95, 2009. Disponível em: <http://www.periodicos.letras.ufmg.br/index.php/nuntius_antiquus/article/view/2033/1 990> Acesso em: 28 ago. 2017.

RIOS, C. M. Philo of Alexandria: an introduction to the Jewish exegete and his intercultural context. Scriptura, Stellenbosch, v. 114. p. 1-13, 2015. Disponível em: <http://scriptura.journals.ac.za/pub/article/view/111>8. Acesso em: 28 ago. 2017.

RIOS, C. M. Uma Torah anti-hedonista em Fílon de Alexandria. Horizonte, v. 13, n. 39, p. 1630-1657, jul. /set. 2015b. Disponível em:

<http://periodicos.pucminas.br/index.php/horizonte/article/view/P.21755841.2015v13n39p1630>. Acesso em: 04 out. 2017.

RUNIA, David T. How to read Philo. In: RUNIA, David T. Exegesis and philosophy: studies on Philo of Alexandria. Aldershot: Variorum, 1990. p. 185-198.

RUNIA, David T. The structure of Philo's allegorical treatises: a review of two recent studies and some additional comments. Vigiliae Christianae, Leiden, v. 38, n. 3, p. 209$256,1984$.

SAMUEL, Michael L. Torah from Alexandria: Philo as a biblical commentator. Volume I: Genesis. New York: Kodesh Press, 2014. 
SHROYER, Montgomery. Alexandrian Jewish literalists. Journal of Biblical

Literature, Atlanta, v. 55, n. 4, p. 261-284, 1936.

SIEGERT, Folker. Philon et la philologie Alexandrine. Aux origines du fondamentalisme biblique. In: INOWLOCKI, S.; DECHARNEUX, B. Philon d'Alexandrie: un penseur à l'intersection des cultures gréco-romaine, orientale, juive et chrétienne. Turnhout:

Brespols, 2011. p. 393-402.

WOLFSON, Harry Austryn. Philo: foundations of religious philosophy in Judaism, Christianity, and Islam. Cambridge: Fifth Printing; London: Harvard University Press, 1982. 